\title{
Research on Strengthening Financial Budget Management of the Funds of Trade Unions in Colleges and Universities
}

\author{
Weiqin LIU \\ Shanghai Second Polytechnic University
}

\begin{abstract}
Budget management of trade unions in colleges and universities can help trade union managers to plan, coordinate, control and evaluate the performance of trade union activities, and promote the smooth progress of trade unions work. This paper analyzes the problems existing in the budget of trade unions in colleges and universities, and puts forward some relevant strategies to strengthen the budget management of trade unions in colleges and universities from improving the business level of grassroots trade union personnel, exerting effective supervision and management, strengthening network construction and management, and strengthening budget performance management.
\end{abstract}

Keywords-Budget; Financial management; Regulation; Efficiency

\section{SignificANCE OF FUND BUdget OF TRADE UNIONS IN} COLLEGES AND UNIVERSITIES

\section{A. Improve the use efficiency of funds}

Attaching importance to the budget management of trade union funds can facilitate the financial income and expenditure activities in the future work of the trade unions, and reduce the blindness and randomness in the work, which can effectively improve the use efficiency of trade union funds and reduce the financial risks of trade unions.

\section{B. Conducive to raising the enthusiasm of grassroots trade unions}

The trade union funds are a powerful guarantee for promoting grassroots work. The budget can clarify the work objectives of each department. Through adequate communication and coordination, the rights and responsibilities of each department are clearly defined; the work objectives and the required funds are organically combined and taken into consideration as a whole to mobilize the enthusiasm of each department.

\section{Conducive to examination and evaluation}

Budget management is carried out in combination with the actual work situation of colleges and universities, and budgets are based on limited trade union a fund, which facilitates the quantitative evaluation of grassroots departments and facilitates the incentive and control of grassroots trade unions.

School Cultivation Subject Finance Program (XXKPY1602) funding.
The more detailed the budget items, the more accurate the data, the more beneficial it is to optimize the structure of trade union expenditures, form an effective internal control mechanism, promote the further development of the trade unions, and also strictly enforce thrift and economy according to the "eight provisions" of the Central Committee [1].

\section{PRINCIPLES OF BUDGET OF TRADE UNIONS IN COLLEGES AND UNIVERSITIES}

\section{A. Adhere to the principle of trade unions serving mass organizations}

Before the budget, first make adjustments based on the previous budget and actual expenditures. If the budget is unreasonable, analyze the reasons and at the same time, fully consider the next work objectives on the original basis. The budget should be centered on the work objectives of trade unions, focusing on the duties of trade unions in colleges and universities, safeguarding the legitimate rights and interests of employees, highlighting the important instructions of General Secretary Jinping XI on mass organization reform and the spirit of the central mass organization reform symposium. The work of trade unions should be inclined to the grassroots and improve the teachers' participation in the work of trade unions. The use of funds should be inclined to the grassroots.

\section{B. Adhere to the principle of safeguarding the legitimate rights and interests of workers}

The basic duty of the trade union is to safeguard the legitimate rights and interests of the workers. The trade unions' budget preparation should reflect the wishes and requirements of the masses, take the interests of the broad masses of workers as the starting point and standpoint, use the limited trade union funds to do good and practical work for the masses of workers, especially in solving problems for difficult workers, and safeguarding the rights and interests of the masses of workers according to law [2].

\section{Adhere to the principle of budget audit system}

Various expense budgets of the trade union should be strictly in accordance with the requirements of the All-China Federation of Trade Unions. The budget should be prepared and reported to the higher authorities for approval. At the same time, internal control should be further improved, budget 
audits should be conducted, and strict implementation should be carried out in accordance with the approved budget to ensure better use of funds and prevent unreasonable use of funds.

\section{PROBLEMS EXISTING IN THE BUDGET OF TRADE UNIONS IN COLLEGES AND UNIVERSITIES}

\section{A. There are misunderstandings in ideological understanding}

The budget preparation is not scientific enough, and the budget implementation is arbitrary. The trade union law strictly regulates: The budget of the labor union funds is the framework and guidance for the one-year work of the trade unions. It is related to whether the work objectives are clear and plays a very important role in the effectiveness of the trade union work [3]. The trade union should establish budget, budget audit and budget performance evaluation according to the principle of budget. However, there are some misunderstandings in the ideological understanding of the budgets of some trade unions in colleges and universities, the preparation is not rigorous, and serious analysis is not carried out in combination with the actual work. The budget preparation is impractical and formal. The budget preparation is not detailed enough; the accuracy and operability are not enough. The budget preparation deviates from the actual work, and the budget execution is arbitrary. If the budget is not prepared properly, it will lead to the blindness of budget implementation, which will reduce the efficiency of budget use.

\section{B. The concept of budget management is not advanced enough}

Without advanced budget management concepts, there will be no reasonable and scientific budget management, which will also make the management benefits generated in the work not high [4]. In the budget management of some trade unions in colleges and universities, the relationship between "social benefits" and "economic benefits" is not considered comprehensively. Without in-depth consideration of the overall objectives of the trade union, the overall participation of the mass organization work, and the consideration of serving the grassroots, plus the lack of overall awareness and responsibility awareness, the budget under this awareness is not conducive to the in-depth, detailed and long-term development of the work of the trade union.

\section{Lack of Internet thinking}

In order to effectively realize the dynamic budget control of enterprise budget, and timely correct the implementation of enterprise budget, more and more enterprises have begun to use the Internet environment to implement the "data + internal supervision" management model. Schools pay more attention to the departments of teaching, research and finance, but attach little importance to the Internet thinking in budget management of the trade unions. There is a lack of internal management construction, data sharing and the trade union's online supervision of budget management [5]. The budget is to arrange work from top to bottom, and the budget is submitted from the next level. In the process of participating in the budget, the next-level trade union department can understand the requirements of the department trade union according to the objectives of the higher-level budget, and understand the unsolved problems of the department that need to be resolved through budget preparation. The process of budgeting is the process of continuous adjustment and modification between superiors and subordinates. The grassroots department can understand the importance and enthusiasm of the work in participating in the budget.

\section{Lack of effective budget monitoring mechanism}

In the entire budget management, there is a lack of a comprehensive and effective budget supervision and control system. Generally, it pays more attention to the afterwards supervision of the use of expenses, and does not pay attention to beforehand budget supervision of the expenses If you can control the expense budget beforehand and do a good job of supervision and management in the use of funds, the work can be carried out better.

\section{E. Lack of performance evaluation}

In the work, we should also conduct comprehensive evaluation of the actual completion of work and the results of expense budget, that is, the performance evaluation of the budget, so as to improve the participation and enthusiasm of the work of the trade union cadres. Some trade unions in colleges and universities lack the concept of scientific budget and performance management, and there is the concept of "preferring income to expenditure, distribution to management, and use to performance". In fact, the budget management of trade unions should not only lie in completing the work according to the plan, but also focus on how to strengthen performance management, so as to improve budget management capabilities [6]. There is a lack of management system in the performance management of trade union budgets, or if there is but it is not perfect and lacks systematicity, these will directly affect the implementation of the budget.

\section{F. Paying no attention to the adjustment of budget preparation}

Some trade unions have only done a one-time job of budget preparation, and make no adjustments for fear of trouble at work, which makes some project funds redundant and wasteful. However, since some of the work was not included in the budget, what should be done is not carried out because there were no funds to promote it. By the end of the year, it is planned as a whole to make a crash use of the funds because the funds are inexhaustible. It losses the due effect of budget and final settlement, resulting in the waste of funds. 


\section{STRATEGIES TO THE BUDGET OF TRADE UNIONS IN COLLEGES AND UNIVERSITIES}

\section{A. Improve the business level of grassroots trade union personnel to improve the quality of budget preparation}

The heads of trade unions should clarify the overall objectives of the work of trade unions in colleges and universities, strengthen the training of grassroots cadres of trade unions through various methods and means, publicize the importance and work objectives of trade unions in colleges and universities, and enable grassroots cadres of the trade unions to understand laws and regulations, trade union regulations and financial budgets, etc., so that they can fully understand the job responsibilities of grassroots trade union cadres, and have the ability to handle the work of the trade unions, establish good mass relationship, and budget the funds according to the basic situation of each grassroots department on such basis. If the grassroots department does not have financial budget authority, there will be no funds. Without funds, it will be difficult to promote the mass organization characteristics of the trade unions' work. In terms of teachers' participation, the superiors cannot fully understand the department and individual situation.

\section{B. Give play to the role of effective supervision and management}

In order to improve the use efficiency of trade union funds, it is necessary to form a trade union fund audit committee to play a supervisory role. Because the fund audit committee members of the grassroots trade unions need to fully understand the economic activities of the trade unions at the same level, the trade union fund audit committee should be selected from the grassroots level, and some enthusiastic personnel who know about accounting should be recommended to participate in the fund audit committee. In the audit process, the preparation and the implementation of the budget should be the focus of the audit. The "source" and "process" should be checked, and the problems can be solved in the bud by the audit of the trade union fund audit committee, thus realizing the effective protection of the trade union assets [7]. In the audit, it is necessary to check whether the use of funds guarantees the needs of the key work of the trade unions, whether the structure of expenditures is reasonable, and whether the budget is refined to facilitate implementation and assessment. At the same time, in the implementation of the budget, it is necessary to follow up the audit according to the budget implementation, reduce the waste in the process of trade union operation, and put the whole process of the economic activities of the trade unions under effective fund audit and supervision.

At the same time, we must give full play to the role of financial supervision and correctly understand the relationship between budget and accounting of trade unions [8]. Accounting is the result of the implementation of trade union budgets. From accounting, it can reflect whether the fund is wasted, the use of funds is insufficient compared with the original budget, or not used, or used concentrate at the end of the year. Therefore, the structure of fund use must be refined when budgeting, and the time node of fund use should also be refined. The use of funds should be combined with the work of the trade unions, and the efficiency of fund use should be improved, to prevent using funds in the budget to obtain funds, or obtaining funds but not completing the work on time.

\section{Strengthen the construction and management of the network}

The Internet is the mouthpiece of trade union propaganda, which can improve the transparency of work, and it is also the window for the trade unions to be supervised. The Internet can improve work efficiency in the process of management, so the trade unions in colleges and universities must also strengthen the thinking of the Internet. Effective trade union budget management can enhance the ability of grassroots union managers and strengthen their loyalty [9].

The trade union Internet needs to achieve networking of the trade union, finance and auditing departments between the lower and upper levels of the trade union. The use of the Internet in the budget is mainly reflected in the following aspects. Budget networking used in the budget can facilitate the finance, trade unions and supervisory departments at different levels to transmit data and information through network sharing. In the process of budget making, they can build a management platform of mutual interaction between finance, budget and audit departments, which can avoid information asymmetry. In the process of budget execution, dynamic changes of data can serve as an entry point for the assessment of grassroots work. The fund audit department should also supervise the use of trade union funds at any time to ensure the correct and efficient use of funds while ensuring the completion of work. If any budget difference is found during the budget execution process, analyze the reasons for the budget difference and correct the difference in time. If it is caused by human factors, the responsibility should be investigated.

In budget supervision, we should actively use the new media means, combine the performance management of trade union budget with the public opinion supervision of the faculty and staff, and let the faculty and staff understand the actual use of the trade union funds through the information disclosure and feedback mechanism. By understanding the use of funds, employees can learn about the work of the trade union, and the participation of the faculty and staff in the work of the trade union can be improved in the future. At the same time, the new media also create a supervision environment for self management within the school, which can promote the continuous improvement of the quality of trade union services.

\section{Strengthen performance management of budget}

The important link that should be fully recognized for the trade union to do a good job in budget management is to strengthen the performance management concept of budget. Trade union management personnel at all levels should strengthen study, learn the responsibilities and mission requirements of trade union work, understand the key points of trade union work, form a good atmosphere for budget performance management within the trade union, and lay a 
solid foundation for the development of trade union budget work.

At the same time, it is necessary to conduct quantitative assessment, establish an effective performance evaluation index system for trade unions, and conduct assessments on the difference ratio of expenditure and budget, the completion rate of work, and the planning of departmental work in the expenditure performance management indexes. By setting up different indicators, we can rationally choose diversified performance evaluation methods.

The trade unions also need to conduct qualitative assessments, to assess whether the expenditure is inclined to serving employees, safeguarding rights and interests, and promoting development, etc., and whether it fully reflects "serving the overall interests, serving grassroots, serving workers", so as to reflect and assess the comprehensive level of trade union budget management. Listen to the opinions of cadres at all levels and the masses on the management of trade unions in written or oral form, sum up experience and lessons, and give appropriate rewards to departments or activities that work well.

In order to avoid the ambiguity of management and assessment objectives, they can be divided into annual goals, semi-annual goals, quarterly targets, monthly targets and special construction. Establish a strict performance management and evaluation accountability mechanism, achieve the implementation of responsibilities at all levels, achieve clear rewards and punishments, and improve the enthusiasm of trade union personnel at all levels in budget performance management.

\section{CONCLUSION}

As a non-profit organization of mass organization nature, the trade unions strengthen the quality of trade union management personnel, emphasize the responsibility and efficiency of budget expenditure in the process of tilting toward mass organizations in management, pay attention to the supervision in the budget process, the adjustment in the middle stage and the performance evaluation in the later stage, thereby continuously improving the use performance of trade union funds.

\section{REFERENCES}

[1] Fang MENG, On How To Strengthen the Budget Management of Trade Unions. Finance and Economics (Academic Edition), 2016(14): Page $57+153$.

[2] Yumei NIE. Raise Awareness of the Budget Management of Grassroots Trade Unions. Research on the Political Work of Oil. 2014(3): Page 63 Page 57+153.

[3] Yingke XU. Analysis on the Development of Financial Work of Trade Unions in Colleges and Universities in the New Era. Studies of Finance and Accounting in Education. 2015(4): Page 93+96.

[4] Yan ZHANG, Research on the Problems and Countermeasures in the Budget Management of Trade Unions in Colleges and Universities. Economist, 2017(03): Page 203-204+207.

[5] Li ZENG, Opinions and Suggestions on Strengthening the Budget Management of Trade Unions. Business Economics, 2016(09): Page $92-$ 93.

[6] Ying FENG, Some Thoughts on Strengthening the Implementation of the Performance Evaluation System for Trade Union Budgets. Administrative Business Assets and Finance, 2016(5): Page 14-15.

[7] Xinghong ZHAI, A Brief Discussion on the Standardized Management of Fund Audit of Trade Unions in Colleges and Universities. Journal of Yangzhou College of Education, 2010(04): Page 23-25.

[8] Ying WANG Problems and Countermeasures of Financial Management Accounting Budget and Accounting of Grassroots Trade Unions. Accounting Audit. 2013(10) Page 343.

[9] Li ZENG, Opinions and Suggestions on Strengthening the Budget Management of Trade Unions. Business Economics, 2016(09): Page 9293. 